\title{
Persepsi Penggunaan Flipped Classroom di Sekolah Dasar selama Pandemi Covid 19
}

\author{
Dodiet Enggar Wibowo*, Ali Mahmudi, Pratiwi Pujiastuti, Meylani Astino Perdana \\ Universitas Negeri Yogyakarta \\ Jl. Colombo No. 1 Karangmalang, Caturtunggal, Depok, Sleman, DIY 55281 \\ *Corresponding Author.e-mail: dodietenggar.2019@student.uny.ac.id
}

\begin{abstract}
Abstrak
Model pembelajaran flipped classroom merupakan pembalikan prosedur pembelajaran tradisional, di mana yang biasanya dilakukan di kelas dalam pembelajaran tradisional menjadi dilaksanakan di rumah dalam flipped classroom. Selama pandemi Covid-19, banyak sekolah dasar menyelenggarakan pembelajaran menggunakan model tersebut. Namun demikian, persepsi guru, orang tua, dan siswa belum terungkap secara baik terkait model pembelajaran ini. Oleh sebab itu, penelitian ini bertujuan untuk mengetahui persepsi guru, orang tua, dan siswa terkait dengan pembelajaran daring menggunakan model flipped classroom selama masa pandemi Covid-19. Metode penelitian yang diterapkan dalam penelitian menggunakan pendekatan kualitatif. Instrumen yang digunakan dalam penelitian adalah pedoman wawancara yang telah divalidasi menggunakan prosedur expert judgement. Wawancara diajukan kepada subjek, yang meliputi: guru, orang tua dan siswa di SDN Margoyasan (3 guru, 3 orang tua, dan 2 siswa), SD Tukangan (2 guru, 2 orang tua, dan 2 siswa), SDN Puro Pakualaman (4 guru, 4 orang tua, dan 2 siswa), dan SD Islamiyah Pakualaman (3 guru, 3 orang tua, dan 2 siswa). Data yang terkumpul dianalisis secara kualitatif untuk menegaskan temuan-temuan penelitian. Hasil penelitian menunjukkan persepsi guru, orang tua, dan siswa terhadap pembelajaran daring menggunakan metode flipped classroom sangat menunjang proses pembelajaran siswa selama masa pandemi Covid-19. Meski begitu, selain ditemukannya persepsi positif subjek, ditemukan pula hambatan-hambatan teknis sehubungan dengan kurangnya fasilitas individual yang dimiliki siswa.
\end{abstract}

Kata Kunci: pembelajaran daring, Flipped Classroom, guru, orang tua, siswa

\section{Perceptions of Implementing Flipped Classroom in Primary Schools during the Covid-19 Pandemic}

\begin{abstract}
The flipped classroom learning model is a reversal of traditional learning procedures, where what is usually done in class in traditional learning is carried out at home in a flipped classroom. During the current Covid-19 pandemic, many elementary schools are holding lessons using this model. However, the perceptions of teachers, parents, and students have not been well disclosed regarding this learning model. Therefore, this research aims to determine the perceptions of teachers, parents, and students regarding online learning using the flipped classroom model during the Covid-19 pandemic. The research method applied in this study uses a qualitative approach. The instrument used in this study was an interview guide that was validated using expert judgment procedures. Interviews were then submitted to the subjects, which included: teachers, parents, and students at SDN Margoyasan (3 teachers, 3 parents, and 2 students), Tukangan Elementary School (2 teachers, 2 parents, and 2 students), SDN Puro Pakualaman (4 teachers, 4 parents and 2 students), and SD Islamiyah Pakualaman (3 teachers, 3 parents, and 2 students). The collected data were analyzed qualitatively to confirm the research findings. The results showed that the perceptions of teachers, parents, and students towards online learning using the flipped classroom method greatly supported the student learning process during the Covid-19 pandemic. Even so, apart from finding positive perceptions of the subject, technical obstacles were also found due to the lack of individual facilities owned by students.
\end{abstract}

Keywords: online learning, Flipped Classroom, teachers, parents, students 
Jurnal Penelitian Ilmu Pendidikan, 14 (2), 2021 - 115

Wibowo, Mahmudi, Pujiastuti, \& Perdana

How to Cite: Wibowo, D. E., Mahmudi, A., Pujiastuti, P. \& Perdana, M. A. (2021). Persepsi penggunaan flipped classroom di sekolah dasar selama pandemi covid-19. Jurnal Penelitian Ilmu Pendidikan, 14(2), 114126. doi: https://doi.org/10.21831/jpipfip.v14i1.37920.

Received 17-01-2021; Received in revised from 05-02-2021; Accepted 06-04-2021

This is an open-access article under the CC-BY-SA license.

\section{PENDAHULUAN}

Pandemi Covid-19 adalah masalah baru dalam dunia pendidikan. Banyak guru, orang tua dan siswa mengalami kebingungan dalam dunia pendidikan. Guru, orang tua, dan siswa bingung mengenai sistem pembelajaran yang cocok digunakan pada saat pandemi Covid-19 ini. Pemerintah Indonesia pada akhirnya memutuskan untuk menyelenggarakan pembelajaran jarak jauh melalui penerbitan Surat Edaran (SE) Kemendikbud No. 15 Tahun 2020. SE tersebut menegaskan bahwa pembelajaran jarak jauh dilaksanakan dengan dua pendekatan, yaitu (1) pendekatan dalam jaringan, dan (2) pendekatan luar jaringan. Lebih lanjut, SE tersebut juga menegaskan bahwa satuan pendidikan boleh memilih pendekatan dalam jaringan, luar jaringan, ataupun keduanya bergantung pada ketersediaan sarana dan prasarana sekolah. Demikianlah, meski sekolah ditutup untuk pelaksanaan pembelajaran tatap muka, pembelajaran tetap berlangsung dengan salah satu atau kedua dari pendekatan di atas tadi. Memang, saat ini satuan pendidikan di zona hijau dan kuning bisa melakukan pembelajaran tatap muka dengan izin dari dinas pendidikan dan satgas percepatan penanganan Covid19 berdasarkan SKB empat menteri No. 03/KB/2020, No. 612 Tahun 2020, No. HK.01.08/Menkes/502/2020, No. 119/4536/SJ. Namun pada prakteknya, banyak sekolah (termasuk sekolah lokasi penelitian ini) belum bisa menyelenggarakan pembelajaran tatap muka. Sebagai gantinya, sekolah menyelenggarakan pembelajaran jarak jauh menggunakan pendekatan dalam jaringan (daring).

Pembelajaran daring merupakan sebuah pembelajaran yang dilakukan dalam jarak jauh melalui media berupa internet dan alat penunjang lainnya seperti telepon seluler dan komputer. Pembelajaran daring sangat berbeda dengan pembelajaran seperti biasa. Pembelajaran daring, menurut Riyana (2019), berfokus kepada kecermatan siswa dalam mengolah berbagai informasi akademik yang disajikan virtual melalui perangkat pendukung pembelajaran daring (contoh: smartphone dan komputer). Konsep pembelajaran daring memiliki konsep yang sama dengan $e$ learning. Namun selama pembelajaran daring berlangsung, banyak orang tua mengeluhkan beberapa masalah yang dihadapi selama peserta didik belajar di rumah, di antaranya: terlalu banyak tugas yang diberikan, dan guru yang belum mengoptimalkan teknologi. Di samping banyaknya keluhan orang tua mengenai pembelajaran daring, ternyata pembelajaran juga memiliki beberapa kelebihan. Adapun beberapa kelebihan dari pembelajaran daring yaitu adanya keluwesan waktu dan tempat belajar, misalnya belajar dapat dilakukan di kamar, ruang tamu dan sebagainya serta waktu yang disesuaikan, misalnya pagi, siang, sore maupun malam. Pembelajaran daring juga dapat mengatasi permasalahan jarak, misalnya peserta didik tidak harus pergi ke sekolah dahulu untuk belajar. Artinya, pembelajaran daring tidak dibatasi secara spasial karena dapat mencakup area yang luas. Meski begitu, perlu ditegaskan kembali bahwa keluhan-keluhan di atas mengindikasikan kekurangan pembelajaran daring yang belum teratasi dengan baik.

Pembelajaran daring, menurut Hadisi \& Muna (2015), berakibat pada interaksi yang minim antara guru dengan siswa. Bahkan, dalam beberapa kasus, minimnya interaksi juga terjadi pada siswa dengan siswa. Rendahnya interaksi tersebut pada gilirannya menghambat terbentuknya values atas kegiatan belajar mengajar yang berlangsung. Terlebih lagi, pembelajaran daring yang dilaksanakan saat ini menjadi hal baru bagi guru maupun siswa. Maksud dan tujuan dari pembelajaran daring adalah memberi pelayanan pembelajaran jarak jauh yang berkualitas, masif, dan terbuka. Tercapainya tujuan ini pada akhirnya akan memberi kesempatan lebih luas untuk siswa (Sofyana \& Rozaq, 2019). Kelemahan lainnya yang terjadi pada pembelajaran daring yaitu anak sulit untuk fokus pada pembelajaran karena suasana rumah yang kurang kondusif, keterbatasan kuota internet atau wifi yang menjadi penghubung dalam pembelajaran daring serta adanya gangguan dari beberapa hal lain. 
Jurnal Penelitian Ilmu Pendidikan, 14 (2), 2021 - 116

Wibowo, Mahmudi, Pujiastuti, \& Perdana

Akibat dari kelemahan pembelajaran daring, muncul permasalahan yang sering dihadapi guru, orang tua, dan siswa yang saling berkesinambungan satu dengan lainnya. Permasalahan tersebut diangkat menjadi masalah utama dalam penelitian ini. Adapun permasalahan ini diperoleh dari wawancara awal sebagai studi pendahuluan di SDN Puro Pakualaman. Wawancara dilakukan kepada 6 orang guru, 6 orang orang tua, dan 5 orang siswa. Respon jawaban yang diperoleh menunjukkan bahwa guru merasa tidak bersemangat dalam mengajar karena mereka tidak dapat berinteraksi dan melakukan observasi secara langsung dengan para siswa. Begitupun dengan siswa yang merasa kurang motivasi dalam mengikuti proses pembelajaran sehingga mereka merasa bosan dan tidak bersemangat dalam belajar. Selain itu para orang tua juga merasa kesulitan dalam pembelian dan pemenuhan paket data yang digunakan dalam proses pembelajaran.

Atas dasar masalah tersebut, guru di sekolah berusaha mengikuti tren kependidikan terkini, yaitu memilih model pembelajaran flipped classroom dan memanfaatkan teknologi informasi untuk kepentingan pendidikan dan pembelajaran. Keputusan tersebut diasumsikan bisa mengatasi masalah di atas tadi, karena telah banyak kasus menunjukkan efektivitas flipped classroom maupun pemanfaatan teknologi informasi untuk kepentingan pembelajaran. Flipped classroom tidak lain adalah model pembelajaran yang dilaksanakan untuk meminimalisasi kuantitas instruksi langsung (Johnson, 2013). Tujuan ini biasa dicapai dengan memanfaatkan berbagai teknologi yang dinilai mampu mendukung tersampaikannya materi pembelajaran tambahan bagi siswa. Selain itu, konsep flipped classroom juga menekankan pada terbukanya akses materi bagi siswa, baik secara daring maupun luring. Meski begitu, perlu dimengerti bersama bahwa instruksi langsung dalam flipped classroom hanya meminimalisasi, bukan dihilangkan. Pada waktunya, instruksi langsung tetap dilaksanakan secara tatap muka. Ketika pembelajaran tatap muka inilah siswa yang telah mengakses dan mempelajari materi secara mandiri melakukan kolaborasi, mengerjakan proyek, saling memberi umpan balik, dan melakukan aktivitas student-centered lainnya.

Flipped classroom, yang disebut juga sebagai flipped learning oleh Lo \& Hew (2017), Mohan (2018), dan Murillo-Zamorano, López-Sánchez, \& Godoy-Caballero (2019), adalah strategi pembelajaran yang menggunakan jenis pendekatan pembelajaran campuran (blended learning) dengan membalikkan lingkungan belajar tradisional dan memberikan konten pembelajaran di luar kelas (sebagian besar online). Selama sesi tatap muka di kelas, dilakukan pembahasan terhadap tugas (bahan yang secara tradisional dianggap sebagai pekerjaan rumah) atau pendidik dapat meminta kelas untuk membahas pertanyaan ujian terkait. Beberapa pendidik melakukan kegiatan menonton video pembelajaran streaming atau berkolaborasi dalam diskusi daring sebagai kegiatan kelas dengan pengawasan cermat oleh fasilitator (Scott, Hsieh, Huang, \& Wu, 2017). Mekanisme flipped classroom yang demikian pada gilirannya memberikan sejumlah keunggulan atau keuntungan. Sebagaimana telah diungkap dalam berbagai penelitian terdahulu, bahwa keuntungan yang bisa diperoleh melingkupi peningkatan motivasi siswa untuk belajar secara mandiri (Havwini \& Wu, 2019), siswa menjadi lebih siap dari aspek kognitif untuk melakukan diskusi langsung (Gariou-Papalexiou, Papadakis, \& Manousou, 2017), dan peningkatan partisipasi belajar siswa, utamanya karena didukung penggunaan teknologi kolaboratif seperti Google Docs, Google Classroom, dan Edmodo (Bond, 2020).

Kelebihan-kelebihan di atas tidak terlepas dari prosedur penggunaan flipped classroom yang memang orientasinya mengarah kepada penyiapan siswa secara mandiri dan individual agar bisa berpartisipasi dalam pembelajaran klasikal. Selama penggunaan flipped classroom, sedikitnya ada empat dasar prinsipil menurut Demirel (2016). Pertama adalah lingkungan belajar yang fleksibel, karena desain flipped learning mengizinkan pembelajaran berlangsung dengan berbagai metode asalkan siswa bisa belajar secara mandiri dan well-prepared. Kedua ialah perubahan budaya belajar dari yang semula berbasis guru menjadi berbasis siswa. Ketiga adalah konten yang telah disiapkan. Maksudnya, guru-lah yang memutuskan materi mana yang seharusnya dipelajari siswa secara mandiri, dan materi mana yang seharusnya dipelajari secara bersama-sama. Keempat adalah pendidik profesional. Hanya karena pembelajaran menjadi berbasis kepada siswa, bukan berarti guru menjadi tidak perlu secara profesional menjalankan tugas fasilitasinya. Ia justru harus tetap memperhatikan konten materi, adaptasi metode pembelajaran, dan memaksimalkan waktu interaksi yang tersedia.

Berdasarkan permasalahan yang telah diuraikan sebelumnya, maka peneliti terdorong untuk meneliti persepsi guru, orang tua, dan siswa terhadap pembelajaran daring dengan metode flipped 
classroom selama pandemi Covid-19. Pengungkapan persepsi ini menjadi penting karena persepsi subjek penelitian berpengaruh terhadap pengambilan keputusan untuk berpartisipasi atau tidak berpartisipasi (Ravlin \& Meglino, 1987), termasuk dalam program belajar di sekolah yang menggunakan flipped classroom.

\section{METODE}

Metode yang digunakan peneliti adalah metode deskriptif, dengan menggunakan pendekatan kualitatif. Metode penelitian kualitatif merupakan metode penelitian naturalistic karena penelitiannya dilakukan pada kondisi yang alamiah (natural setting), dan data yang terkumpul dianalisis secara kualitatif (Sugiyono, 2014). Melalui analisis kualitatif tersebut, menurut Creswell (2012), akan diperoleh pemahaman yang luas, mendetail, dan lengkap mengenai persepsi dan pandangan dari pada informan. Sebab, dalam analisis data kualitatif pasti akan melalui fase interpretasi secara tematik untuk menegaskan temuan-temuan penelitian (Berg, 2004). Metode kualitatif dipandang relevan penelitian kependidikan ini karena dipandang sangat efektif untuk mendeskripsikan kondisi yang terjadi pada saat ini, yaitu pembelajaran daring pada masa pandemi. Pembelajaran daring inilah yang kemudian oleh Creswell (2014) disebut sebagai central phenomenon.

Subjek dalam penelitian ini adalah guru, orang tua dan siswa di SDN Margoyasan (3 guru, 3 orang tua, dan 2 siswa), SD Tukangan (2 guru, 2 orang tua, dan 2 siswa), SDN Puro Pakualaman (4 guru, 4 orang tua, dan 2 siswa), dan SD Islamiyah Pakualaman (3 guru, 3 orang tua, dan 2 siswa). Subjek dipilih melalui purposive sampling, dengan kriteria pemilihan subjek guru ialah merupakan guru yang sudah aktif melaksanakan flipped classroom selama masa tanggap darurat Covid-19. Sebagaimana lazimnya diperlukan dalam penelitian kualitatif, purposive sampling diperlukan sebagai usaha untuk mendapatkan subjek yang mempunyai kesesuaian kriteria dengan tujuan dan objek penelitian (Bassey, 1999). Pemilihan subjek tersebut dilatarbelakangi karena tujuan dari penelitian ini yaitu bagaimana persepsi subjek terhadap pembelajaran daring dengan metode flipped classroom, serta faktor-faktor apa saja yang menjadi pendukung dan penghambat guru dalam proses pembelajaran daring untuk guru sekolah dasar.

Pengumpulan data dalam peneliti ini menggunakan teknik wawancara terstruktur. Teknik wawancara terstruktur dipilih karena peneliti sudah menentukan secara pasti informasi apa saja yang hendak dikumpulkan selama wawancara berlangsung (Silverman, 2013). Oleh karena itu, wawancara terstruktur mensyaratkan adanya pedoman wawancara sebagai acuan baku pengajuan pertanyaan kepada informan (Masyhud, 2014). Pedoman wawancara dalam penelitian ini sebagaimana disajikan dalam Tabel 1. Guna memastikan bahwa pedoman tersebut layak digunakan, maka dilakukan validasi isi (content validity) yang ditempuh melalui expert judgement. Aspek yang dinilai oleh pakar (expert) ialah (1) aspek kebahasaan, untuk memastikan bahwa bahasa yang digunakan sesuai dan bisa memfasilitasi penyampaian maksud dari pertanyaan yang diajukan, dan (2) aspek konten, untuk memastikan bahwa isi pertanyaan yang diajukan sudah mewakili objek penelitian yang hendak dikaji.

Tabel 1. Pedoman Wawancara

\begin{tabular}{|c|c|}
\hline $\begin{array}{c}\text { Subjek } \\
\text { Penelitian }\end{array}$ & Pertanyaan \\
\hline Guru & $\begin{array}{l}\text { 1. Bagaimanakah pelaksanaan kegiatan pembelajaran di sekolah tempat Anda } \\
\text { mengajar setelah terjadinya pandemi Covid-19? } \\
\text { 2. Jenis aplikasi apa saja yang dipergunakan pada saat melaksanakan kegiatan } \\
\text { pembelajaran daring dan coba jelaskan tentang aplikasi tersebut? } \\
\text { 3. Bagaimanakah pelaksanaan pembelajaran daring dengan menggunakan metode } \\
\text { flipped classroom? }\end{array}$ \\
\hline Orang tua & $\begin{array}{l}\text { 1. Bagaimanakah persepsi Anda pada saat pembelajaran dengan menggunakan } \\
\text { media-media daring menggunakan metode flipped classroom? } \\
\text { 2. Menurut Anda apakah efektif pembelajaran daring dengan menggunakan } \\
\text { metode flipped classroom yang dipergunakan? }\end{array}$ \\
\hline Siswa & $\begin{array}{l}\text { 1. Kendala apakah yang dihadapi dalam pembelajaran menggunakan metode } \\
\text { flipped classroom dengan menggunakan media-media daring? }\end{array}$ \\
\hline
\end{tabular}


Jurnal Penelitian Ilmu Pendidikan, 14 (2), 2021 - 118

Wibowo, Mahmudi, Pujiastuti, \& Perdana

Wawancara dilakukan secara tatap muka di sekolah (bagi informan guru) dan di rumah masing-masing (bagi informan siswa dan orang tua). Selama wawancara, jawaban informan tidak ditulis tangan di lembar kertas, melainkan direkam menggunakan sound recorder. Keputusan ini diambil guna mengefektifkan berlangsungnya wawancara agar lebih komunikatif, natural, dan untuk menghargai pembicaraan oleh informan. Hasil wawancara lisan kemudian ditranskrip sehingga menjadi tulisan, untuk kemudian dianalisis secara kualitatif dengan mengikuti langkah-langkah analisis data yang dikemukakan oleh Miles, Huberman, \& Saldana (2014), meliputi: data condensation, data display, dan conclusion drawing/verification.

\section{HASIL DAN PEMBAHASAN}

\section{Hasil}

\section{Guru}

Berdasarkan hasil pengumpulan data, pembelajaran daring sifatnya sangat terbatas dalam memberikan pemahaman terhadap siswa. Sistemnya hanya memberikan tugas kepada siswa dan pelaksanaannya tetap sama dengan jadwal mata pelajaran pada umumnya dengan menggunakan RPP yang sebelumnya. Hasil ini diperoleh dari jawaban responden yang dikutip oleh peneliti. Salah satu hasil wawancara yang dikutip oleh peneliti sebagai berikut.

"Ya selama pandemi menerapkan pembelajaran daring. Ketika pembelajaran daring peserta didik hanya mengulang, jadi tidak begitu banyak memberikan materi yang sifatnya menerangkan. Selama proses pembelajaran daring, semua tugas yang dikerjakan wajib dituliskan dalam satu buku yang sama. Pembelajaran dilaksanakan sesuai jadwal pelajaran. Tidak ada perbedaan penggunaan RPP dalam proses pembelajaran daring dan yang seperti biasa, semuanya sama" (Wawancara: 19 Oktober 2020; jam 09:00 WIB. Wali kelas V SD Negeri Margoyasan).

Potongan wawancara di atas menunjukkan bahwa persepsi guru tentang penerapan pembelajaran flipped classroom kurang komprehensif. Ini dibuktikan dengan banyaknya kelebihankelebihan dari flipped classroom yang tidak diberdayakan dengan baik oleh guru. Dalam praktiknya, memang pembelajaran telah memanfaatkan kelebihan flipped classroom, yaitu fleksibilitas waktu beserta mekanisme pembelajaran, dan pengubahan budaya belajar dari berbasis guru menjadi berbasis siswa. Namun begitu, pembelajaran sebagaimana dalam kutipan di atas sekaligus menunjukkan diabaikannya potensi keunggulan lain dari flipped classroom. Potensi keunggulan tersebut adalah sebagaimana disebut Akçayır \& Akçayır (2018) sebagai kontribusi pedagogis, peningkatan kemampuan pebelajar, dan interaksi yang efektif.

Idealnya, penerapan pembelajaran flipped classroom yang baik pasti akan memberikan sejumlah keuntungan tadi. Namun bukti wawancara di atas mengungkapkan bahwa flipped classroom dalam persepsi guru adalah pengubahan gaya belajar tatap muka menjadi gaya belajar campuran, di mana pembelajaran tatap muka diisi dengan aktivitas mengulang apa-apa saja yang sudah dipelajari siswa secara mandiri. Padahal Demirel (2016) pernah menegaskan bahwa flipped classroom juga menganut prinsip profesionalitas. Artinya, guru bukan hanya mengulang materi, melainkan guru harus juga memastikan beberapa hal, seperti: relevansi materi yang hendak diberikan dalam pembelajaran tatap muka, kemampuan siswa dalam beradaptasi dengan metode pembelajaran, dan maksimal atau tidaknya waktu yang tersedia untuk interaksi siswa dengan guru dan siswa dengan siswa lainnya.

Barangkali persepsi yang kurang lengkap inilah yang kemudian mendorong dimanfaatkannya WhatsApp sebagai aplikasi paling dominan dalam pembelajaran flipped classroom. Aplikasi ini dimanfaatkan dengan merujuk kepada model pembelajaran flipped classroom dan memaksimalkan penggunaannya menjadi sebuah aplikasi dengan melihat kebutuhan pendidikan dan pembelajaran saat ini. Argumen ini didasarkan kepada salah satu contoh kutipan wawancara di bawah ini.

"Melalui flipped classroom. Karena lebih mudah dan praktis. Namun, harus dibantu media lewat grup whatsapp untuk memudahkan komunikasi antara guru, orang tua dan siswa. Aplikasi ini juga dibuat berdasarkan metode pembelajaran flipped classroom dengan melihat kebutuhan pendidikan pada kondisi saat ini" (Wawancara: 19 Oktober 
2020; jam 10:00 WIB. Wali kelas VI SD Islamiyah Pakualaman). "Untuk melihat kondisi waktu sangat efisien. Akan tetapi, masih mengalami kendala seperti harus mempersiapkan materi berupa video dan berupa hand out" (Wawancara: 19 September 2020; jam 11:00 WIB. Wali kelas IV SD Negeri Tukangan).

Hasil wawancara di atas menunjukkan bahwa penggunaan WhatsApp sebagai aplikasi yang dominan didasarkan atas sejumlah pertimbangan. Namun pertimbangan yang paling penting adalah daya suportif aplikasi tersebut terhadap kelancaran interaksi tidak langsung antara guru dengan siswa selama siswa sedang mempelajari materi pembelajaran secara mandiri. Selain kelancaran interaksi tidak langsung, pertimbangan lainnya adalah karena penggunaan WhatsApp mampu membantu guru mengelola waktu menjadi lebih efisien. Hanya saja, masih menurut guru, penggunaan flipped classroom dengan dibantu media daring belum tentu menjadikan pembelajaran menjadi efektif, sekalipun bisa dipandang efisien dari segi waktu.

Guru menganggap penerapan flipped classroom berbantuan WhatsApp kurang efektif karena dalam praktiknya memang guru tidak bisa melakukan observasi menyeluruh kepada semua siswa. Terlebih lagi, dalam flipped classroom, siswa belajar secara mandiri di rumah mereka masing-masing. Persepsi yang demikian itu diwakili oleh salah satu informan yang mengatakan: "Kurang, karena guru tidak dapat memantau anak secara langsung apakah peserta didik sudah mampu memahami materi yang disampaikan oleh guru" (Wawancara: 20 September 2020; jam 09:00 WIB. Wali kelas V SD Negeri Puro Pakualaman.

Memang, guru bisa saja memastikan apakah siswa sudah memahami materi atau belum dengan melakukan tes sederhana pada saat tatap muka. Namun pada kenyataannya, persepsi yang didominasi pemahaman bahwa flipped classroom adalah sebatas pembelajaran campuran nampaknya berpengaruh terhadap keputusan guru untuk melakukan asesmen pencapaian penguasaan materi oleh siswa. Di samping itu, guru juga tampak mengalami mispersepsi mengenai konsep dari flipped classroom. Seperti yang disampaikan informan dalam petikan wawancara berikut.

"Keterbatasan antara guru dengan peserta didik dikarenakan belajar jarak jauh. Siswa merasa tidak bersemangat dalam mengikuti belajar. Selain itu, keterbatasan paket data. Karena dalam belajar online ini harus banyak paket data" (Wawancara: 19 September 2020; jam 08:30 WIB. Wali kelas IV SD Negeri Margoyasan)

Berdasarkan kutipan wawancara di atas, tampak bahwa guru menganggap flipped classroom sebagai pembelajaran yang hanya bisa dilaksanakan menggunakan perangkat yang terkoneksi internet. Padahal substansi dari flipped classroom adalah mengurangi interaksi, bukan mengganti prosedur interaksi. Karena guru terpaku pada pemahaman bahwa flipped classroom hanya bisa dilaksanakan dengan bantuan internet, maka pada akhirnya pembelajaran tidak berkembang. Sebagai dampak atas hambatan yang tidak terselesaikan dengan solusi di atas menyebabkan siswa tidak bersemangat, kurang motivasi dalam belajar, interaksi yang kurang secara kualitas dan kuantitas, dan lain sebagainya.

\section{Orang Tua}

Ada beberapa persepsi orang tua dalam memandang flipped classroom yang berhasil ditemukan dalam penelitian ini. Salah satu persepsi yang paling menonjol adalah anggapan bahwa pembelajaran menggunakan desain flipped classroom memerlukan pendampingan dari orang tua secara penuh. Padahal sebagaimana disebutkan di bagian awal tulisan ini, salah satu tujuan diterapkannya flipped classroom adalah mendorong siswa agar belajar secara mandiri, kemudian mengasah keterampilan kolaboratif mereka ketika pembelajaran tatap muka berlangsung.

Atas adanya persepsi ini, beberapa orang tua mengeluhkan cara kerja pembelajaran daring. Sebab mereka merasa berkewajiban untuk mendampingi anak secara tuntas sejak awal sampai akhir pembelajaran. Sebenarnya para orang tua telah menyadari bahwa pembelajaran daring dalam desain flipped classroom dibantu dengan fasilitas WhatsApp, tetapi persepsi ini pada akhirnya menjadikan orang tua melakukan pendampingan pembelajaran secara tuntas sejak awal sampai selesai. Persepsi ini sebagaimana diwakili oleh dua pernyataan orang tua di bawah ini.

"Pembelajaran online ini sangat menguras tenaga dan pikiran, karena kita sebagai orang tua harus mendampingi anak mulai dari jam belajar sampai jam belajar berakhir. Sehingga waktu kita tersita” (Wawancara: 21 Oktober 2020; jam 08:00 WIB. 
Jurnal Penelitian Ilmu Pendidikan, 14 (2), 2021 - 120

Wibowo, Mahmudi, Pujiastuti, \& Perdana

Orang tua siswa SD Negeri Margoyasan). "Melalui flipped classroom dan dibantu dengan group whatsapp. Karena harus dibantu media lewat grup whatsapp untuk memudahkan komunikasi antara guru, orang tua dan siswa" (Wawancara: 21 Oktober 2020; jam 09:00 WIB. Orang tua siswa SD Negeri Margoyasan). Orang tua cenderung menginginkan pembelajaran secara tatap muka secara penuh. Asumsi ini diperkuat dengan pernyataan informan yang ketika diwawancarai mengatakan: "Saya rasa lebih bagus belajar tatap muka daripada belajar online" (Wawancara: 21 Oktober 2020; jam 09:40 WIB. Orang tua siswa SD Negeri Margoyasan).

Bagi orang tua, pembelajaran daring dalam desain flipped classroom yang selama pandemi ini dilaksanakan tidak efektif. Sebab selain adanya kendala teknis seperti kurangnya paket data yang bisa diusahakan orang tua, rupanya orang tua menyadari bahwa anak-anak mereka kurang bersemangat dalam menjalani pembelajaran daring. Kurangnya efektivitas dan rendahnya motivasi belajar tersebut sebagaimana tergambarkan dalam kutipan wawancara terhadap informan berikut.

"kurang, karena paket data cepat habis. Selain itu,anak saya kurang bersemangat kalau mau belajar. Sehingga harus dibujuk terlebih dahulu agar anak saya mau belajar" (Wawancara: 21 Oktober 2020; jam 10:40 WIB. Orang tua siswa SD Negeri Margoyasan).

Namun terlepas dari keluhan-keluhan yang ditemukan dari wawancara di atas, orang tua juga mempunyai persepsi lain yang seolah menjadi anti-tesis atas persepsi semula. Bahwa pada akhirnya orang tua juga harus belajar untuk aktif mendukung pembelajaran anaknya. Selain menyesuaikan diri dengan cara kerja perangkat pendukung pembelajaran daring, orang tua juga membuka diri terhadap berbagai informasi yang disebarkan oleh sekolah. Tujuannya adalah agar anak mendapatkan hasil yang baik meski pembelajaran daring ini mengalami banyak hambatan. Argumentasi ini sebagaimana disebutkan oleh informan.

"Saya sendiri sebagai orang tua harus belajar lebih banyak, untuk mengikuti peraturan sekolah. Agar anak saya tidak ketinggalan informasi dari sekolah" (Wawancara: 21

Oktober 2020; jam 10:20 WIB. Orang tua siswa SD Negeri Margoyasan).

\section{Siswa}

Berbeda dengan gagasan-gagasan pokok yang disampaikan dalam sejumlah teori dan penelitian, persepsi siswa dalam pembelajaran daring di penelitian ini menunjukkan ketidaksenangan. Berdasarkan hasil wawancara terhadap informan siswa, mereka merasa lebih nyaman dan senang diajar secara langsung (tatap muka) sebagaimana pembelajaran sebelum adanya pandemi. Meski begitu, rupanya ketidaksenangan siswa bukan bersumber dari mekanisme pembelajaran daring maupun sumber belajar, melainkan karena pengajar yang memfasilitasi pembelajaran mereka. Melalui wawancara, salah satu informan mengatakan,

"Tidak, karena tidak ada guru mengajari saya secara langsung. Lebih senang belajar

langsung diajari dan dibimbing ibu guru daripada belajar sama ibu atau ayah saya"

(Wawancara: 23 September 2020; jam 08:30 WIB. siswa SD Negeri Margoyasan).

Pada dasarnya, tidak banyak kesimpulan yang bisa diketengahkan berdasarkan hasil wawancara di atas. Sebab persepsi siswa tentang penggunaan flipped classroom merujuk kepada tokoh pengajar, bukan pada prosedur. Bagi mereka, bisa saja pembelajaran flipped classroom dianggap sebagai pembelajaran yang diselenggarakan oleh orang tua, bukan guru. Namun demikian, hasil wawancara terhadap informan lain mengungkapkan adanya proses adaptasi siswa terhadap prosedur pelaksanaan pembelajaran daring dalam desain flipped classroom. Sebagaimana dikutip peneliti berikut, salah satu informan mengaku,

"Saya rasa ada kesusahan pertama sekali menggunakannya. Tapi setelah terbiasa sudah tidak susah lagi" (Wawancara: 21 Oktober 2020; jam 09:20 WIB. siswa SDN Margoyasan).

Hanya saja, kendala-kendala teknis (misal: masalah kuota internet) tetap menjadi persoalan yang masih ada dalam persepsi setiap kelompok subjek penelitian, sebagaimana dinyatakan oleh informan berikut. 
Jurnal Penelitian Ilmu Pendidikan, 14 (2), 2021 - 121

Wibowo, Mahmudi, Pujiastuti, \& Perdana

"Saya kurang bersemangat belajar. Karena belajarnya jarak jauh. Kadang paket data saya habis, sehingga perlu waktu untuk mengisi paket data" (Wawancara: 21 Oktober 2020; jam 10:30 WIB. siswa SD Negeri Margoyasan).

Kendala-kendala teknis semacam ini tidak bisa dianggap remeh, sebab kendala teknis bisa saja menjadi kendala psikologis berupa penurunan motivasi belajar siswa. Apabila sudah demikian, maka perlu dilakukan berbagai inovasi pembelajaran yang merangsang peningkatan motivasi siswa untuk berpartisipasi dalam pembelajaran. Salah satu yang terbukti efektif adalah dengan memberikan variasi penyampaian materi seperti contoh dalam kutipan wawancara berikut.

"Kadang-kadang saya merasa senang, karena bisa bermain game setelah selesai belajar. Saya lebih senang belajar online menggunakan aplikasi flipped classroom.

Karena ada dibuat video dan tampilannya saya suka" (Wawancara: 21 Oktober 2020;

jam 10:00 WIB. siswa SD Negeri Margoyasan).

Demikianlah ada tiga corak dalam persepsi siswa mengenai flipped classroom. Pertama ialah pembelajarannya tidak lebih menyenangkan daripada pembelajaran tatap muka. Kedua adalah diperlukannya waktu beberapa saat untuk melaksanakan pembelajaran flipped classroom dengan baik (adaptasi siswa). Ketiga ialah pembelajaran dengan desain bisa menjadi menyenangkan jika materinya dikemas dengan tampilan visual yang sesuai dengan minat atau setidak-tidaknya sesuai dengan karakteristik anak usia sekolah dasar

\section{Pembahasan}

Berdasarkan hasil penelitian dengan metode kualitatif deskriptif melalui teknik pengumpulan data berupa wawancara yang telah dilakukan pada guru, orang tua dan siswa, telah diperoleh informasi tentang proses pembelajaran daring dan flipped classroom serta faktor-faktor pendukung dan faktor-faktor penghambatnya. Adapun berdasarkan temuan di lapangan dapat ditarik kesimpulan bahwa, pandemi Covid-19 sangat berdampak pada dunia pendidikan. Pandemi ini mengakibatkan proses pembelajaran menjadi sangat terganggu. Semula, proses pembelajaran dilaksanakan dengan tatap muka langsung antara guru dan peserta didik di kelas, tetapi pandemi seolah memaksa hampir semua penyelenggara pendidikan untuk melakukan pembelajaran daring (Adedoyin \& Soykan, 2020; Mishra, Gupta, \& Shree, 2020).

Akibatnya, sebagaimana banyak dikatakan oleh guru subjek penelitian ini, bahwa pembelajaran daring bagi siswa sekolah dasar masih mengalami banyak kendala. Sebagai contohnya ialah keikutsertaan peserta didik dalam pembelajaran tidak mencapai $100 \%$ dalam pembelajaran daring. Ada pula beberapa peserta didik yang bahkan tidak mengikuti pembelajaran sama sekali dari awal hingga akhir, sehingga guru merasa bingung dalam proses penilaian peserta didik tersebut. Utamanya untuk menentukan apakah ia sudah menguasai kompetensi yang ditargetkan ataukah belum. Masalah penilaian ini menjadi penting karena menurut penelitian Lapitan, Tiangco, Sumalinog, Sabarillo, \& Diaz (2021) asesmen menjadi runtutan terakhir yang paling penting dalam serangkaian proses blended learning yang efektif. Sebagai usulan solusinya, masalah yang demikian bisa diatasi dengan penerapan flipped classroom. Sebab melalui cara ini, siswa bisa belajar secara daring sekaligus tatap muka dalam satu rangkaian program belajar. Selain solutif atas persoalan tersebut, terdapat sejumlah kelebihan lain sebagaimana disebutkan Shi-Chun, Ze-Tian, \& Wang (2018).

Proses pembelajaran daring dilaksanakan sesuai dengan jam pembelajaran yang sebelumnya sudah ditentukan, termasuk juga pembelajaran daring yang dilaksanakan oleh guru menggunakan flipped classroom. Namun, pembelajaran tersebut dibantu dengan WhatsApp sebagai media guru untuk mempermudah komunikasi antara guru, orang tua dan siswa. Dewi (2020) berpendapat, belajar daring dapat menggunakan teknologi digital, namun yang pasti harus dilakukan adalah pemberian tugas melalui pemantauan pendampingan oleh guru melalui WhatsApp Group sehingga anak betulbetul belajar. Guru harus berkoordinasi dengan orang tua, bisa melalui video call maupun foto kegiatan belajar anak di rumah untuk memastikan adanya interaksi antara guru dengan orang tua. WhatsApp diusulkan sebagai salah media interaksi yang efektif karena merupakan platform yang 
paling populer untuk menunjang pembelajaran daring, sekalipun di kawasan pedesaan (Setiawan \& Iasha, 2020).

Pembelajaran daring membawa dampak kepada peserta didik. Dampak yang dialami oleh peserta didik yaitu mereka merasa sangat jenuh dan bosan atas pembelajaran. Semangat dan antusias yang ditunjukkan oleh peserta didik semakin harinya semakin menurun. Kondisi tersebut berbeda dengan kondisi saat peserta didik belajar di kelas bersama teman-temannya. Dampak lain dari pandemi Covid-19, menurut Putri et al. (2020), terhadap peserta didik yaitu sekolah diliburkan terlalu lama membuat anak-anak jenuh. Anak-anak mulai jenuh di rumah dan ingin segera ke sekolah bermain dengan teman-temannya, peserta didik terbiasa berada di sekolah untuk berinteraksi dengan teman-temannya, bermain dan bercanda gurau dengan teman-temannya serta bertatap muka dengan para gurunya. Sejumlah dampak turunan ini berasal dari dampak induk, yaitu terganggunya kegiatan belajar mengajar, dan tidak siapnya lembaga pendidikan sekaligus pengajarnya untuk mengatasi gangguan-gangguan tersebut. Sehingga alternatif terbaik yang bisa dilakukan adalah dengan menerapkan pembelajaran jarak jauh (Sari, Tusyantari, \& Suswandari, 2021).

Sehubungan dengan kendala pembelajaran jarak jauh, penelitian ini juga mengungkap adanya kendala lain melalui berbagai persepsi guru dan siswa selama melaksanakan pembelajaran jarak jauh menggunakan flipped classroom. Bagi guru, siswa dianggap cukup mempunyai rasa tanggung jawab apabila ia sudah mampu mengikuti pembelajaran dan mengisi daftar hadir pembelajaran daring. Peserta didik sering mengeluh karena hanya diberikan tugas terus menerus. Padahal kenyataannya, guru merasa kurang nyaman karena tidak dapat memberikan materi pembelajaran secara langsung kepada peserta didik dan hanya memberikan tugas. Cara untuk mengatasi rasa jenuh tersebut guru berinisiatif untuk memberikan media pembelajaran yang menarik seperti video, namun kebanyakan dalam pembelajaran daring guru mengalami kendala atau keterbatasan dalam menggunakan media pembelajaran. Pada kondisi-kondisi seperti ini, maka persepsi yang kurang optimis bisa diatasi dengan promosi kerjasama antara pihak sekolah dengan pihak orang tua atau wali murid. Sebagaimana dalam penelitian Rahmi (2020), kerjasama sekolah dengan orang tua banyak ditempuh sekolah-sekolah untuk mengatasi berbagai hambatan pembelajaran daring selama pandemi Covid-19. Namun jika memang sekolah mampu mengupayakan fasilitasi, maka hendaknya sekolah menggunakan platform e-learning. Sebab platform e-learning biasanya lebih efektif daripada kerjasama karena ia hampir menyerupai sekolah virtual (Hariani \& Wastuti, 2020). Meski begitu, dalam hal efektivitas interaksi dan mutu pembelajaran, penelitian ini mengungkapkan bahwa persepsi subjek pada umumnya masih menganggap flipped classroom sebagai desain pembelajaran terbaik.

Metode flipped classroom dibagi menjadi tiga kegiatan (Ozdamli \& Asiksoy, 2016) yaitu, sebelum kelas dimulai (pre-class), saat kelas dimulai (in-class) dan setelah kelas berakhir (out of class). Sebelum kelas dimulai, peserta didik sudah mempelajari materi yang akan dibahas terlebih dahulu di rumah, dalam tahap ini kemampuan yang diharapkan dimiliki oleh peserta didik adalah mengingat (remembering) dan mengerti (understanding) materi. Dengan demikian pada saat kelas dimulai peserta didik dapat mengaplikasikan (applying) dan menganalisis (analyzing) materi melalui berbagai kegiatan interaktif di dalam kelas, yang kemudian dilanjutkan dengan mengevaluasi (evaluating) dan mengerjakan tugas berbasis project tertentu sebagai kegiatan setelah kelas berakhir (creating). Sesuai dengan tren perkembangan pendidikan saat ini, terlepas dari pandemi atau tidak, desain pembelajaran ini merupakan desain pembelajaran yang paling kompatibel dan cocok untuk era digital (Susanti \& Hamama-Pitra, 2019). Artinya, dengan persepsi subjek penelitian sebagaimana terungkap dalam tulisan ini, maka flipped classroom tetap bisa diterapkan meski pandemi covid-19 sudah berlalu.

Berdasarkan hasil penelitian ini, baik guru, orang tua, dan siswa menunjukkan masalah yang sama, yaitu tidak adanya motivasi dalam mengikuti proses pembelajaran daring. Akibatnya nilai dan pengetahuan akademik siswa menjadi sangat buruk. Sehingga memang perlu adanya interaksi secara langsung antara guru dan siswa, selain hanya interaksi dengan daring. Dua bentuk interaksi ini hanya bisa dicapai dengan melakukan pembelajaran dengan desain flipped classroom. Sebagaimana dikatakan Schrire (2006), bahwa siswa memperoleh luaran pembelajaran yang lebih baik secara akademis manakala mereka ikut serta dalam serangkaian diskusi dengan sesama siswa daripada serangkaian diskusi dengan guru. Bentuk interaksi dalam pembelajaran flipped classroom sebelumnya sudah pernah diteliti oleh Song \& McNary (2011). Ia meneliti interaksi melalui diskusi yang diukur 
dengan jumlah posting dan log-in dengan hasil akademik. Hasil penelitian itu menunjukkan bahwa rupanya ada korelasi antara jumlah posting dan skor. Studi ini menjadi salah satu hal yang dapat membuktikan bahwa guru dan siswa memang sangat dianjurkan adanya interaksi secara langsung maupun tidak langsung.

Kegiatan interaktif antara guru dan siswa, menurut penelitian Kang \& Im (2013), berdampak pada hasil belajar siswa yang melaksanakan kegiatan pembelajaran, seperti asistensi belajar, keintiman sosial, komunikasi dan tanya jawab instruksional, kehadiran instruktur, dan instruksional dukung. Telah banyak penelitian yang mengusulkan solusi untuk menjadikan kegiatan interaktif secara efektif mendukung proses pembelajaran siswa. Salah satu contoh usulan itu dicetuskan oleh Evans \& Sabry (2003), yang melaksanakan tiga kegiatan interaktif, yaitu kontrol kecepatan, penilaian diri, dan simulasi interaktif beserta waktu penggunaan sistem. Tiga kegiatan ini merupakan faktorfaktor yang mempengaruhi hasil belajar siswa, baik secara akademik maupun sosial. Siswa yang melaksanakan tiga kegiatan tersebut memperoleh hasil belajar yang lebih baik daripada siswa yang tidak melaksanakan. Selain itu, Evans \& Sabry (2003) juga menegaskan bahwa siswa yang melaksanakan tiga kegiatan tersebut cenderung membutuhkan waktu belajar yang lebih sedikit, daripada siswa yang melaksanakan interaksi dengan sistem yang tersedia di perangkat komputer maupun internet. Namun penelitian ini tidak dilakukan dengan bentuk interaktif lainnya. Demikian pula menurut hasil penelitian Damianov, Kupczynski, \& Calafiore (2009), yang menegaskan adanya pengaruh positif terhadap arah waktu yang dihabiskan secara daring dan hasil tersebut dihitung dengan skor siswa, terutama siswa pada kelompok di atas rata-rata.

Oleh karena itu, sebagai acuan bersama, perlu kiranya untuk menyimpulkan makna pembelajaran interaktif dalam flipped classroom dengan merujuk kepada definisi yang ditawarkan Chou, Peng \& Chang (2010). Bahwa pembelajaran yang interaktif adalah pembelajaran yang memungkinkan terjadinya interaksi antara siswa dengan siswa lain, siswa dengan guru atau sebaliknya, siswa dengan bahan ajar atau materi, bahkan siswa dengan dirinya sendiri melalui aktivitas intelektual. Sebab itulah, suatu pembelajaran perlu direvitalisasi dengan merujuk pada kebutuhan warga sekolah (Khoiron et al., 2020). Sebab itu pula, hendaknya bahan ajar dalam flipped classroom didesain menjadi bahan ajar interaktif, misalnya video pembelajaran yang bisa diputar beberapa kali di rumah (S̆pilka, 2016).

\section{PENUTUP}

Proses pembelajaran yang dilaksanakan guru berubah, yang biasanya pembelajaran dilaksanakan secara langsung menjadi pembelajaran daring. Pembelajaran daring dirasa kurang efektif bagi guru terutama untuk anak usia sekolah dasar. Pembelajaran dilaksanakan secara daring maka guru kurang merasa maksimal dalam memberikan materi pembelajaran sehingga menjadikan materi tidak tuntas dan penggunaan media pembelajaran dalam pembelajaran daring dirasa tidak maksimal. Peserta didik merasa jenuh akan pembelajaran daring, mereka bosan dengan pemberian tugas setiap harinya. Peserta didik menjadi malas dalam mengerjakan tugas, hal tersebut menjadikan pengumpulan tugas menjadi sangat terlambat sehingga menjadikan guru sulit melakukan penilaian. Proses penilaian yang diberikan oleh guru memiliki sistem yang sama dengan pembelajaran biasanya. Terdapat beberapa faktor pendukung dalam pembelajaran daring diantaranya adalah handphone, kuota dan jaringan internet yang stabil. Faktor pendukung tersebut dimanfaatkan guru semaksimal mungkin dalam memantau perkembangan peserta didik melaksanakan pembelajaran daring. Selain adanya faktor pendukung terdapat juga hambatan yang dirasakan guru dalam pembelajaran, hambatan tersebut diantaranya adalah belum semua peserta didik memiliki handphone dan masih banyak orang tua yang sibuk bekerja. Orang tua menjadi seseorang yang sangat penting dalam pelaksanaan pembelajaran daring, karena orang tua secara yang secara langsung terlibat dalam membimbing dan mengawasi peserta didik dalam pembelajaran. Pemberian motivasi menjadi sangat berarti bagi peserta didik, hal tersebut dilakukan agar peserta didik kembali semangat meskipun belajar dari rumah. 
Jurnal Penelitian Ilmu Pendidikan, 14 (2), 2021 - 124

Wibowo, Mahmudi, Pujiastuti, \& Perdana

\section{DAFTAR PUSTAKA}

Adedoyin, O. B., \& Soykan, E. (2020). Covid-19 pandemic and online learning: the challenges and opportunities. Interactive Learning 1-13. https://doi.org/10.1080/10494820.2020.1813180.

Akçayır, G., \& Akçayır, M. (2018). The flipped classroom: A review of its advantages and challenges. Computers and Education, 126, 334-345. https://doi.org/10.1016/j.compedu.2018.07.021.

Bassey, M. (1999). Doing qualitative research in educational settings: Case study research in educational settings. California: Open University Press.

Berg, B. L. (2004). Qualitative research method for social science (5th ed.). New York: Pearson Education.

Bond, M. (2020). Facilitating student engagement through the flipped learning approach in K-12: A systematic review. Computers and Education, 151, 103819. https://doi.org/10.1016/j.compedu.2020.103819.

Chou, C, H., Peng, \& Chang, C, Y. (2010). The technical framework of interactive functions for course-management systems: Students' perceptions, uses, and evaluations. Computers and Education, 55(3), 1004-1017.

Creswell, J. W. (2012). Educational research: Planning, conducting, and evaluating quantitative and qualitative research (4th ed.). New York: Pearson Education. https://doi.org/10.1017/CBO9781107415324.004.

Creswell, J. W. (2014). Research design: Qualitative, quantitative and mixed methods approaches (4th ed.). Singapura: Sage Publication.

Damianov, D. S., Kupczynski, L., \& Calafiore, P. (2009). Time spent online and student performance in online business courses: A multinomial logit analysis. Journal of Economics and Finance Education, 8(2), 11-22.

Demirel, E. E. (2016). Basics and key principles of flipped learning: Classes upside down. International Journal of Languages, Literature and Linguistics, 2(3), 109-112. https://doi.org/10.18178/ijll1.2016.2.3.77.

Dewi, W. A. F. (2020). Dampak covid-19 terhadap implementasi pembelajaran daring di sekolah dasar. Edukatif: Jurnal Ilmu Pendidikan, 2(1), 55-61.

Evans, C., \& Sabry, K. (2003). Evaluation of the interactivity of web-based learning systems: principles and process. Innovations in Education and Teaching International, 40(1), 89-99. https://doi.org/10.1080/1355800032000038787.

Gariou-Papalexiou, A., Papadakis, S., Manousou, E. (Gelly), \& Georgiadu, I. (2017). Implementing a flipped classroom: A case study of biology teaching in a Greek high school. Turkish Online Journal of Distance Education, 18(3), 47-65. https://doi.org/10.17718/tojde.328932.

Hadisi, L., \& Muna, W. (2015). Pengelolaan teknologi informasi dalam menciptakan model inovasi pembelajaran ( e-learning ). Jurnal Al-Ta'dib, 8(1), 117-140.

Hariani, P. P., \& Wastuti, S. N. Y. (2020). Pemanfaatan e-learning pada pembelajaran jarak jauh di masa pandemi covid-19. Biblio Couns: Jurnal Kajian Konseling dan Pendidikan, 3(1), 41-49. https://doi.org/10.30596/bibliocouns.v3i2.4656.

Havwini, T., \& Wu, Y.-T. (2019). The implementation of flipped classroom in EFL class: A Taiwan case study. Journal of Digital Education, Communication, and Arts (Deca), 2(02), 79-88. https://doi.org/10.30871/deca.v2i02.1536.

Johnson, G. B. (2013). Student perceptions of the flipped classroom. London: The University Of British Columbia.

Kang, M., \& Im, T. (2013). Factors of learner-instructor interaction which predict perceived learning outcomes in an online learning environment. Journal of Computer Assisted Learning, 29(3), 292-301. https://doi.org/10.1111/jcal.12005.

Khoiron, M., \& Wahyuningtyas, N. (2020). Revitalization of Social studies education: A developmental study based on dick and carey instructional design. In International Conference on Social Studies and Environmental Issues (ICOSSEI 2019), pp. 38-43. Atlantis Press. https://dx.doi.org/10.2991/assehr.k.200214.007. 
Jurnal Penelitian Ilmu Pendidikan, 14 (2), 2021 - 125

Wibowo, Mahmudi, Pujiastuti, \& Perdana

Lapitan, L. D., Tiangco, C. E., Sumalinog, D. A. G., Sabarillo, N. S., \& Diaz, J. M. (2021). An effective blended online teaching and learning strategy during the covid-19 pandemic. Education for Chemical Engineers, 35, 116-131. https://doi.org/10.1016/j.ece.2021.01.012.

Lo, C. K., \& Hew, K. F. (2017). A critical review of flipped classroom challenges in K-12 education: possible solutions and recommendations for future research. Research and Practice in Technology Enhanced Learning, 12(1). https://doi.org/10.1186/s41039-016-0044-2.

Masyhud, M. S. (2014). Metode penelitian pendidikan. Jakarta: Lembaga Pengembangan Manajemen dan Profesi Kependidikan.

Miles, M. B., Huberman, A. M., \& Saldana, J. (2014). Qualitative data analysis: A methods sourcebook (3rd ed.). Singapura: Sage Publication. https://doi.org/10.1080/0140528790010406.

Mishra, L., Gupta, T., \& Shree, A. (2020). Online teaching-learning in higher education during lockdown period of COVID-19 pandemic. International Journal of Educational Research Open, 1, 100012. https://doi.org/10.1016/j.ijedro.2020.100012.

Mohan, D. (2018). Flipped classroom, flipped teaching and flipped learning in the foreign/second language post-secondary classroom. Nouvelle Revue Synergies Canada, 11(11), 1-12. https://doi.org/10.21083/nrsc.v0i11.4016.

Murillo-Zamorano, L. R., López-Sánchez, J. Á., \& Godoy-Caballero, A. L. (2019). How the flipped classroom affects knowledge, skills, and engagement in higher education: Effects on students' satisfaction. Computers and Education, 141(June). https://doi.org/10.1016/j.compedu.2019.103608.

Ozdamli, F., \& Asiksoy, G. (2016). Flipped classroom approach. World Journal on Educational Technology, 8(2), 98-105. https://doi.org/10.18844/wjet.v8i2.640.

Putri, R. S., Purwanto, A., Pramono, R., Asbari, M., Mayesti Wijayanti, L., \& Chi Hyun, C. (2020). Impact of the covid-19 pandemic on online home learning: An explorative study of primary schools in Indonesia. International Journal of Advanced Science and Technology, 29(5), 4809-4818.

Rahmi, R. (2020). Inovasi pembelajaran di masa pandemi covid-19. AL-TARBIYAH: Jurnal Pendidikan (The Educational Journal), 30(2), 111-123. https://doi.org/10.24235/ath.v30i2.6852.

Ravlin, E. C., \& Meglino, B. M. (1987). Effect of values on perception and decision making: A study of alternative work values measures. Journal of Applied Psychology, 72(4), 666-673. https://doi.org/10.1037/0021-9010.72.4.666.

Riyana, C. (2019). Produksi bahan pembelajaran berbasis online. Jakarta: Universitas Terbuka.

Sari, R. P., Tusyantari, N. B., \& Suswandari, M. (2021). Dampak pembelajaran daring bagi siswa sekolah dasar selama covid-19. Jurnal Ilmiah Kependidikan, 2(1), 9-15. https://doi.org/10.37478/jpm.v2i1.732.

Schrire, S. (2006). Knowledge building in asynchronous discussion groups: Going beyond quantitative analysis. Computers \& Education, 46(1), 49-70. https://doi.org/10.1016/j.compedu.2005.04.006.

Scott, J., Hsieh, C., Huang, Y., \& Wu, W. V. (2017). Computers in human behavior technological acceptance of LINE in flipped EFL oral training. Computers in Human Behavior, 70, 178190. https://doi.org/10.1016/j.chb.2016.12.066.

Setiawan, B., \& Iasha, V. (2020). Covid-19 pandemic: The influence of full-online learning for elementary school in rural areas. Jurnal Pendidikan Sekolah Dasar, 6(2), 114-123.

Shi-Chun, D., Ze-Tian, F., \& Wang, Y. (2018). The flipped classroom - Advantage and challenges. International Conference on Economic Management and Trade Cooperation (EMTC 2014), 39(6), 17-20. https://doi.org/10.1353/abr.2018.0093.

Silverman, D. (2013). Doing qualitative research (4th ed.). Singapura: Sage Publication.

Sofyana, L., \& Rozaq, A. (2019). Pembelajaran daring kombinasi berbasis whatsapp pada kelas karyawan prodi teknik informatika universitas PGRI Madiun. Jurnal Nasional Pendidikan Teknik Informatika, 8(1), 81-86.

Song, L., \& McNary, S. W. (2011). Understanding students' online interaction: Analysis of discussion board postings. Journal of Interactive Online Learning, 10(1), 1-14. 
Jurnal Penelitian Ilmu Pendidikan, 14 (2), 2021 - 126

Wibowo, Mahmudi, Pujiastuti, \& Perdana

Špilka, R. (2016). Learner-content interaction in flipped classroom model. International Journal of Information and Communication Technologies in Education, 4(3), 53-61. https://doi.org/10.1515/ijicte-2015-0014.

Sugiyono. (2014). Metode penelitian pendidikan pendekatan kuantitatif, kualitatif, dan $R \& D$. Bandung: Alfabeta.

Susanti, L., \& Hamama-Pitra, D. A. (2019). Flipped classroom sebagai strategi pembelajaran pada era digital. Health \& Medical Journal, 1(2), 54-58. https://doi.org/10.33854/heme.v1i2.242. 